\title{
Application of Chitosan for Peripheral Nerve Repair
}

\author{
Mehrnaz Moattari ${ }^{1}$, Farahnaz Moattari², Gholamreza Kaka ${ }^{3 *}$ and Homa Mohseni Kouchesfahani ${ }^{1}$ \\ ${ }^{1}$ Department of Animal Biology, Kharazmi University, Iran
}

${ }^{2}$ Faculty of Agriculture and Natural Resources, Persian Gulf University, Iran

${ }^{3}$ Neuroscience Research Center, Baqiyatallah University of Medical Sciences, Iran

Submission: September 04, 2018; Published: October 01, 2018

*Corresponding author: Gholamreza Kaka, Neuroscience Research Center, Baqiyatallah University of Medical Sciences, Aghdasie, Artesh Boulevard, Artesh Square, PO Box: 19568-37173, Tehran, Iran; Fax: +982126127286; Tel: +989123844874; Email: homamohseni123@gmail.com

\begin{abstract}
Regeneration and repair of peripheral nerves, as a prevalent medical problem was not satisfying and complete. This clinical problem is in accompany with loss of innervation in arms or legs, leading to the loss of motor and sensory function. Although, this problem is not lifethreatening, impose socio-economical pressure on individual and society. The worst case of a peripheral nerve trauma is the total disruption of the nerve (neurotmesis), which requires realignment. Chitosan, a natural polysaccharide, synthesized from chitin which is abundant in shrimps and crabs skeleton. Chitosan has excellent biocompatibility and biodegradability can be used as nerve conduit material. The purpose of this work was to study the ability of chitosan and some chitosan-derived materials to promote behavioral, functional and histological assessments in peripheral nerve regeneration and repair. Here, we mentioned the investigations about using chitosan and chitosan derivatives on regeneration and repair of peripheral nervous injuries.
\end{abstract}

Keywords: Chitosan; Peripheral nervous injury; Regeneration; Repair

\section{Introduction}

Chitosan (CS) is a polysaccharide achieved from $\mathrm{N}$-deacetylation of chitin and it is a copolymer of D-glucosamine and $\mathrm{N}$-acetyl-D-glucosamine. Nowadays there is increasing interest in CS in the field of tissue engineering, because it has anti-tumour and antibacterial activities, and also have biodegradabile and biocompatibile properties [1]. There is a similarity between Chitosan and glycosaminoglycans which is found in the basal membrane and extracellular matrix. It has important role in providing interactions between this chitinderivative and extracellular adhesive molecules such as laminin, fibronectin and collagen. So, much attention is focused on CS as a candidate material for neuroregeneration. It is reported that use of chitosan fibers make a similar guide for regenerating axons to Bungner bands in the nervous system by supporting the adhesion, migration and proliferation of Schwann cells (SCs) $[1,2]$. In this regard, a mixture of hydroxyapatite to provide mechanical support, chitosan derived from crab tendons and laminin to increase the growth of regenerating axons applied for regeneration and repair of a $15 \mathrm{~mm}$ defect in a rat sciatic model [3].

In this study, histomorphic results showed improvement but functional and behavioral assessments did not improve in comparison with isograft group [4]. In another study, laminin which was conjugated to chitosan membrane used as a scaffold
[5]. Laminin gave the membrane a flexible property which leads to better interaction with receptors in comparison with laminin alone [6]. Since progesterone and pregnenolone, the precursor of progesterone has important role in myelination, in a study, investigators used chitosan for delivery of progesterone to the site of injury in a rabbits' facial nerve injury model $[7,8]$ by significantly increasing the number of myelinated fibres and the regenerated area when compared to chitosan group [9]. At the site of injury, there was no evidence of inflammatory response and infection. The spongy forms of chitosan conduit increase the permeability and have beneficial effects on nerve regeneration. Since the duration of progesterone release was not enough for nerve regeneration, investigators used a crosslinking format of progesterone to chitosan conduit. This form of combination had three properties for chitosan scaffolds including reduction of swelling degree and rate of degradation and also enhancing their hydrophilicity and elasticity. In this regard, hexa methylene di iso cyanate cross linking to chitosan increased fibronectin and laminin adsorption which leads to an increase in the spread and proliferation of Schwann cells [10].

Using chitosan conduits had appropriate mechanical properties and the rate of degradation is low [11]. It is reported that a mixture of chitosan and gelatin improved the elasticity and increase the ability for adhesion of axon regeneration [12]. Chitosan and poly-l-lysin had higher hydrophile surface in 
comparison with collagen and improves the nerve regeneration [13].

\section{Conclusion}

Now a days, one serious health problem is peripheral nerve injury. Tissue engineering as an interdisciplinary field which combined life science and engineering is promising in regeneration and repair of peripheral nerve injuries. Scaffolds are noticeable components of tissue engineering and regenerative medicine which helps proper growth of regenerating axons on its bed. Scaffolds should be biocompatible, biodegradable, nontoxic, anti-inflammatory, anti-bacterial properties. Chitosan has similar molecular structure to components of extracellular matrix and is a promising candidate material for nerve regeneration.

\section{References}

1. van der Lubben IM, Kersten G, Fretz MM, Beuvery C, Verhoef JC, et al. (2003) Chitosan microparticles for mucosal vaccination against diphtheria: oral and nasal efficacy studies in mice. Vaccine 21(13-14): 1400-1408.

2. Bunge RP (1994) The role of the Schwann cell in trophic support and regeneration. J Neurol 242(1): S19-S21.

3. Itoh S, Yamaguchi I, Suzuki M, Ichinose S, Takakuda K, et al. (2003) Hydroxyapatite-coated tendon chitosan tubes with adsorbed laminin peptides facilitate nerve regeneration in vivo. Brain Res 993(1-2): 111123.

4. Matsuda A, Kobayashi H, Itoh S, Kataoka K, Tanaka J (2005) Immobilization of laminin peptide in molecularly aligned chitosan by covalent bonding. Biomaterials 26(15): 2273-2279.

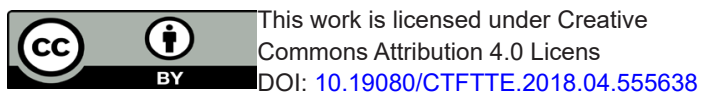

5. Kato K, Utani A, Suzuki N, Mochizuki M, Yamada M, et al. (2002) Identification of neurite outgrowth promoting sites on the laminin $\alpha 3$ chain G domain. Biochemistry 41(35): 10747-10753.

6. Klein CL, Scholl M, Maelicke A (1999) Neuronal networks in vitro: formation and organization on biofunctionalized surfaces. J Mater Sci Mater Med 10(12): 721-727.

7. Désarnaud F, Do Thi AN, Brown AM, Lemke G, Suter U, et al. (1998) Progesterone stimulates the activity of the promoters of peripheral myelin protein-22 and protein zero genes in Schwann cells. J Neurochem 71(4): 1765-1768.

8. Koenig HL, Schumacher M, Ferzaz B, Thi AN, Ressouches A, et al. (1995) Progesterone synthesis and myelin formation by Schwann cells. Science 268(5216): 1500-1503.

9. Chávez-Delgado ME, Mora-Galindo J, Gómez-Pinedo U, Feria-Velasco A, Castro-Castañeda S, et al. (2003) Facial nerve regeneration through progesterone-loaded chitosan prosthesis. A preliminary report. J Biomed Mater Res Part B Appl Biomater An Off J Soc Biomater Japanese Soc Biomater Aust Soc Biomater Korean Soc Biomater 67(2): 702-711.

10. Cao W, Cheng M, Ao Q, Gong Y, Zhao N, et al. (2005) Physical, mechanical and degradation properties, and Schwann cell affinity of cross-linked chitosan films. J Biomater Sci Polym Ed 16(6): 791-807.

11. Cheng M, Deng J, Yang F, Gong Y, Zhao N, et al. (2003) Study on physical properties and nerve cell affinity of composite films from chitosan and gelatin solutions. Biomaterials 24(17): 2871-2880.

12. Cheng D, Xia H, Chan HSO (2004) Facile Fabrication of AgCl@ Polypyrrole-Chitosan Core-Shell Nanoparticles and Polymeric Hollow Nanospheres. Langmuir 20(23): 9909-9912.

13. Wang X, Hu W, Cao Y, Yao J, Wu J, et al. (2005) Dog sciatic nerve regeneration across a $30-\mathrm{mm}$ defect bridged by a chitosan/PGA artificial nerve graft. Brain 128(8): 1897-1910.

\section{Your next submission with Juniper Publishers will reach you the below assets}

- Quality Editorial service

- Swift Peer Review

- Reprints availability

- E-prints Service

- Manuscript Podcast for convenient understanding

- Global attainment for your research

- Manuscript accessibility in different formats

( Pdf, E-pub, Full Text, Audio)

- Unceasing customer service

\section{Track the below URL for one-step submission}

https://juniperpublishers.com/online-submission.php 